\title{
CEO origin, CEO tenure, and earnings quality: empirical evidence from Indonesia
}

\author{
Poppy Nurmayanti $\mathrm{M}^{1, *}$ and Fu'ad Rakhman ${ }^{2}$ \\ ${ }^{1}$ Doctoral Student in Accounting Department, Faculty of Economics and Business, Universitas \\ Gadjah Mada, , Jl. Sosio Humaniora No.1 Bulaksumur,Yogyakarta 55281, Indonesia \\ ${ }^{2}$ Accounting Department, Faculty of Economics and Business, Universitas Gadjah Mada, Jl. Sosio \\ Humaniora No.1 Bulaksumur, Yogyakarta 55281, Indonesia
}

\begin{abstract}
This study examines whether CEO origin and tenure affect earnings quality. Using firms listed in the Indonesia Stock Exchange between 2012 and 2014, we provide evidence that firms with insider CEOs report earnings of higher quality relative to those with outsider CEOs. We further show that as CEO tenure increases and CEOs obtain more experience, the effect of CEO origin on earnings quality becomes less significant.
\end{abstract}

\section{Introduction}

This study examines the effects of Chief Executive Officer (CEO) origin and tenure on earnings quality. CEO origin is associated with whether from the CEO was hired from inside or outside the company. An insider CEO is one that has been working for the company prior to the appointment to the CEO position. An outsider CEO, on the contrary, is hired from outside the company. CEO origin is one of the demographic characteristics that potentially affect the crucial decision-making by CEOs, such as accounting decisions [1]. The upper echelons theory states that managers' demographic characteristics are associated with their cognitive styles and values that affect the manager managerial decision-making [2]. Further, Shen and Cannella found that outsider CEOs has a stronger association with corporate performance than insider CEO [3]. The study also finds that outsider CEOs tend to have a shorter tenure than insider CEO $[3,4,5]$.

Outsiders CEOs face stronger pressure to demonstrate their capabilities, and thus have more incentives to manage earnings, especially in their early years. Kuang et al. find that outsider CEOs have stronger incentives to manage earnings at the beginning of the tenure years following the appointment as CEO, when compared to insider CEO [5]. This study extends Kuang et al. to test whether CEO origin affects earnings quality by incorporating CEO tenure as a moderating variable [4].

This study uses discretionary accruals as a proxy for earnings quality by using accrual estimation error from the Dechow and Dichev model. We also use the modified Jones model to measure accruals quality as an additional analysis.

We find that in general, insider CEOs report earnings of higher quality than outsider CEOs. Further tests indicate that the result is prevalent only when CEO tenure is less than the median value (less than five years). When CEO tenure reaches five year or longer, the superior earnings quality associated with insiders CEOs is no longer present. This is

${ }^{*}$ Corresponding authors: poppynurmayanti@yahoo.com, frakhman@ugm.ac.id 
consistent with the view that since outsider CEOs face greater pressure to show results, they tend to manage earnings early in their tenure years, lowering earnings quality. This results in a lower earnings quality for firms with outsider CEOs relative to those with insider CEOs. However, when they survived the early years, they no longer have as great incentives to manage earnings. Consequently, after five years, there is no longer any significant difference in earnings quality between firms with insider and those with outsider CEOs.

This study has several important contributions. This study contributes to the accounting literature by providing evidence on the effect CEO origin on earnings quality and how CEO tenure moderates the association between the two variables. This study provides insight to investors and board of directors that hiring CEOs from within provides an advantage in the form of higher earnings quality, at least in the early years, relative to hiring outsiders.

\section{Literature Review and Hypothesis Development}

\subsection{CEO Origins}

High earnings quality reflects the company's operational performance more accurately [6]. Dechow et al. argues that higher quality earnings provide more information about the features of a firm's financial performance that are relevant to a specific decision made by a specific decision maker [7]. Previous studies have examined the determinants of earnings quality with a focus on the characteristics or background of top managers. The results of these studies provide mixed results [8].

One aspect stakeholders need to consider when appointing a new CEO is CEO origin. Shen and Cannella argue that outsider CEOs are usually hired when companies desire that their leadership take a new direction [3]. Further, CEOs are hired from outside when the company has a poor performance. This situation requires an outsider CEO to be hired to immediately address the problems and take actions quickly. Consequently, outsider CEOs from are likely to face greater pressure from board of directors and the market to show his managerial ability to achieve results immediately.

Davidson et al. define that a CEO is an insider when the CEO has worked for the company for more than six years. CEOs working for the company for less than six years are classified as outsiders [9]. Kuang et al. [5] describe that CEOs recruited from outside the companies often take advantage of his opportunity as CEO to demonstrate their capability to improve corporate performance [5]. This is useful for his career, so that the labor market can assess and evaluate the CEO's capabilities by comparing it with the CEO recruited from inside the company. Wieserma and Shen and Cannella argued that CEOs from outside the company have stronger interests to report better performance in the long term however, the outsider CEOs tend to have expectations for survival in the company lower than the insider CEOs $[4,3]$.

There are several advantages to recruit outsider CEO; (1) CEO from outside company more demonstrated his/her ability to improve his/her career [5, 10], and (2) CEO from outside company has the advantage that a company's reputation is maintained especially when companies facing financial distressed or poor performance [11]. Appointment of insider CEO has two advantages, are: (1) inside CEO is to have a better understanding about the internal condition of the company, product, market and competition, and a closer relationship with the client, and (2) inside CEO is to have better social networks, so that they can obtain specific information [12].

Kuang et al. [5] found that CEOs recruited from outside the company have stronger incentives to manage earnings at the beginning of the tenure years when compared to 
insider CEOs [5]. This implies that outsider CEOs manage earnings more than insider CEOs. Outsider CEOs feel more pressure to to demonstrate good performance early in their tenur years. Therefore, it is expected that outside CEOs will manage earnings more intensively than insider CEOs, especially in the beginning of their tenure years.

\subsection{CEO Tenure}

Existing empirical evidence find that the market cannot accurately judge the ability of a CEO at the beginning his tenure [12], especially when the CEO does not have previous experience as a CEO. Newly hired CEOs are aware that the market evaluates their ability based on the past and current performance [13]. Thus, to build a reputation in the market and to avoid being labeleld as "low skill" managers, CEOs in early tenure years are likely to have a strong incentive to report good performance. Thus, if the actual performance of certain periods is lower than expected, CEOs have strong incentives to puff up the company's income through aggressive reporting.

Zhang concludes that CEOs with longer tenure are less likely to be aggressive in financial reporting compared CEOs with shorter tenure [13]. CEOs who have longer tenure will try to maintain their reputation, so the CEOs are less aggressive. Further, Ali and Zhang found that CEOs at the beginning of their tenure overstate reported accounting earnings instead of at the end of tenure [14]. The new executives need to prove to the stakeholders of their performance at the beginning of their tenure to quickly obtain recognition and job security.

Kim and Yang provides empirical evidence that a board of directors with longer tenure has a positive impact on financial reporting quality [15]. Specifically, these findings concluded that the boards of directors with longer tenure are associated with lower discretionary accruals. On the contrary, Santoso provides different evidence that CEOs who have a longer tenure actually reported higher discretionary accruals than CEOs with a shorter tenure [16].

\subsection{Hypotheses Statements}

Based on the arguments in the previous sections, we propose the following the hypothesis: H1: Insider CEOs report earnings of higher quality than outsider CEOs.

H2: As CEO tenure increases, the effect of CEO origin on earnings quality become less significant.

\section{Research Methodology}

\subsection{Population and Sampling}

The study uses firms listed in the Indonesian Stock Exchange (IDX) from 2012 to 2014 as the sample. Following other studies, firms in the financial sector are excluded from the sample. Table 1 Panel A describes the sample selection procedure. The initial sample size is 1,448 firm-years. After eliminating financial firms, public firms younger than two years old, those with missing financial data or with insufficient information about CEO details, and outliers, we obtain a total sample of 632 firm-years for the study. Table 1 Panel B shows that the majority of the CEOs are insiders (88.9\%), while the longest tenure is 48 years and the shortest tenure is 1 year. Further, the table shows that the average age of CEO is 52.87 years old, with the oldest is 85 years old and the youngest is 29 years old. 


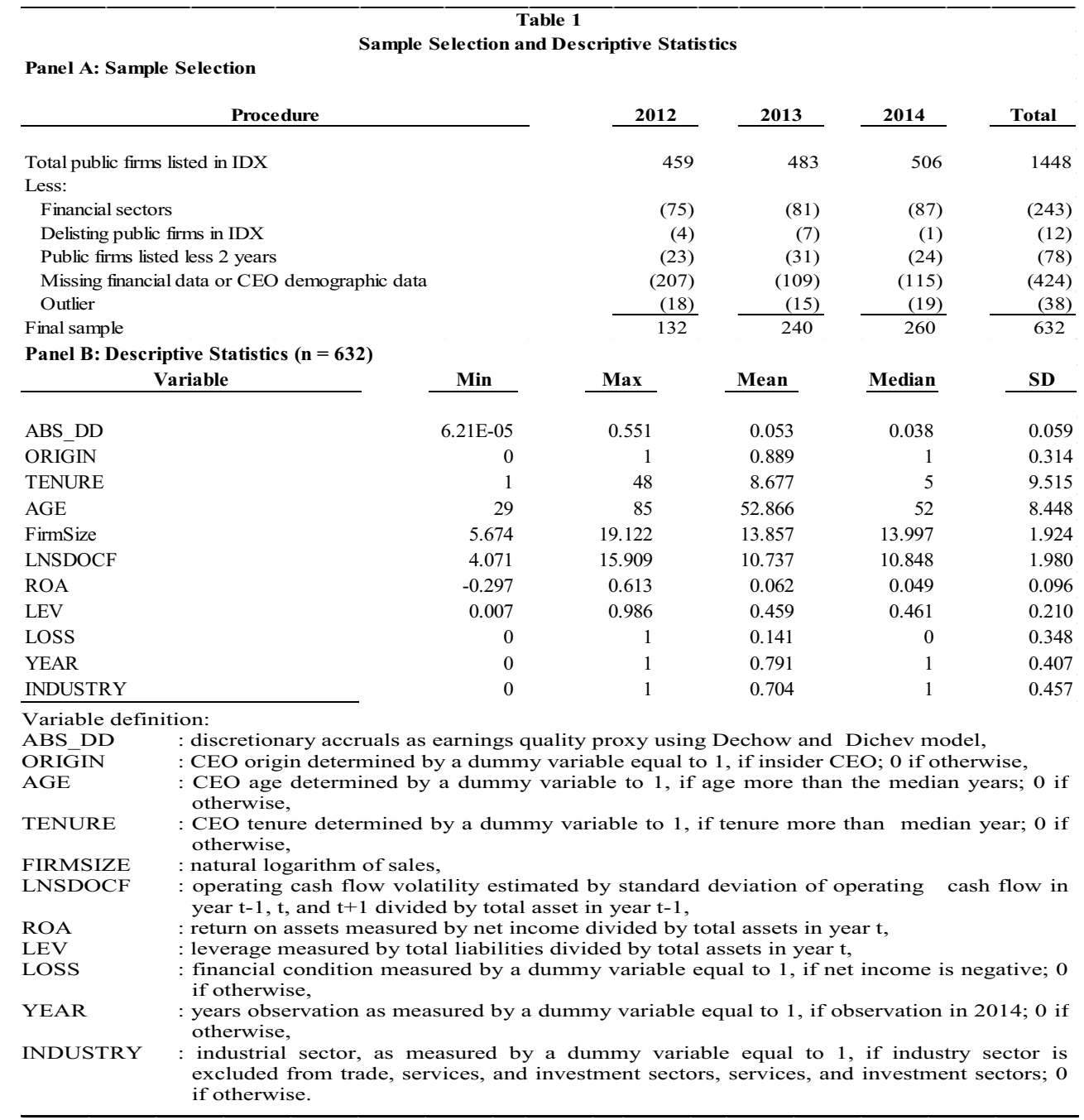

\subsection{Research Model and Variable Measurement}

We follow Dechow and Dichev (2002) to calculate the discretionary accruals [17]. The following equation (1) presents the research model, with absolute value of accrual estimation error or $A B S \_D D$ obtained from Dechow and Dichev (2002) as the dependent variable. A higher value of $A B S \_D D$ indicates lower earnings quality, and vice versa [18, 13].

$$
\begin{aligned}
A B S_{-} D D_{i t}= & \propto_{0}+\propto_{1} \text { ORIGIN }+\propto_{2} \text { AGE }+\propto_{3} \text { TENURE }+\propto_{4} \text { Firmsize }+ \\
& \propto_{5} \text { LNSDOCF }+\propto_{6} \text { LEV }+\propto_{7} \text { ROA }+\propto_{8} \text { LOSS }+\propto_{9} \text { Industry }+ \\
& \propto_{10} \text { Year }+\varepsilon
\end{aligned}
$$

To estimate ABS_DD, we calculate total accruals $\left(\mathrm{TA}_{\mathrm{it}}\right)$ with the following equation (2) below.

$$
\frac{T A_{i t}}{A_{i t-1}}=\alpha_{0}+\alpha_{1} \frac{O C F_{i t-1}}{A_{i t-1}}+\alpha_{2} \frac{O C F_{i t}}{A_{i t-1}}+\alpha_{3} \frac{O C F_{i t+1}}{A_{i t-1}}+\varepsilon_{i t}
$$

$\mathrm{TA}_{\mathrm{it}}$ is the total accruals calculated as net income minus operating cash flow; $A_{i t-1}$ is the total assets of the firm $i$ from year $t-1, O C F_{i t-1}$ is the operating cash flow in the 
year $t-1 ; O C F_{i t}$ is the operating cash flows of year $t ; O C F_{i t+1}$ is the operating cash flow in the year $t+1$; and $\varepsilon_{i t}$ is error term. CEO origin is a dummy variable set to 1 if the CEO is an insider and 0 otherwise. Insider CEO is defined as in Davidson et al. [12]. We also define CEO tenure as a dummy variable set to 1 if CEO tenure is less than the median tenure of CEO (shorter tenure), and if 0 otherwise. Following previous studies (e.g. Wang 2006), this study includes some control variables such as CEO's age, firm's size, the volatility of cash flow operating ( $L N S D O C F), R O A$, leverage ( $L E V)$ and negative earnings (LOSS) [19].

\section{Result}

Table 2 shows that the variable ORIGIN for the regression with the full sample has a negative impact on the size of absolute discretionary accruals. The result implies that the insider CEOs report a lower discretionary accruals than the outsider CEO. In other words, insider CEOs report higher earnings quality than outsider CEOs. The result supports H1.

\begin{tabular}{|c|c|c|c|c|c|c|}
\hline \multirow{4}{*}{$\begin{array}{l}\text { Independent } \\
\text { Variable }\end{array}$} & \multicolumn{6}{|c|}{$\begin{array}{c}\text { Table } 2 \\
\text { Regression Results for the Impact of CEO Origin on Earnings Quality }\end{array}$} \\
\hline & \multicolumn{6}{|c|}{ Dependent Variables $\left(A B S \_D D\right)$} \\
\hline & \multicolumn{2}{|l|}{ Short-term $(<5$ years $)$} & \multicolumn{2}{|c|}{ Long-term $(\geq 5$ years $)$} & \multicolumn{2}{|c|}{ Full Sample } \\
\hline & Coefficient & t-statistic & Coefficient & $t$-statistic & Coefficient & $t$-statistic \\
\hline ORIGIN & $-0.021 * *$ & -2.414 & 0.024 & 1.421 & $-0.016 * *$ & -2.205 \\
\hline TENURE & & & & & $-0.008 *$ & -1.757 \\
\hline \multicolumn{7}{|c|}{ Control Variables } \\
\hline$A G E$ & 0.006 & 0.803 & -0.007 & -1.361 & -0.001 & -0.156 \\
\hline FIRMSIZE & $-0.009 * * *$ & -3.728 & $-0.004 * *$ & -2.022 & $-0.006 * * *$ & -4.204 \\
\hline LNSDOCF & 0.002 & 1.050 & 0.000 & 0.152 & 0.001 & 1.017 \\
\hline$L E V$ & $0.038 * *$ & 2.319 & 0.016 & 1.132 & $0.029 * * *$ & 2.582 \\
\hline$R O A$ & $0.209 * * *$ & 5.774 & $0.162 * * *$ & 4.896 & $0.194 * * *$ & 7.621 \\
\hline LOSS & $0.044 * * *$ & 4.664 & $0.023 * *$ & 2.518 & $0.039 * * *$ & 5.790 \\
\hline$Y E A R$ & $0.025 * * *$ & 2.862 & 0.009 & 1.509 & $0.017 * * *$ & 3.182 \\
\hline INDUSTRY & -0.010 & -1.366 & $-0.014 * * *$ & -2.567 & $-0.013 * * *$ & -2.772 \\
\hline $\mathrm{n}$ & 348 & & 284 & & 632 & \\
\hline Adj R2 & $16.91 \%$ & & $10.27 \%$ & & $15 \%$ & \\
\hline F-statistic & 8.846 & & 4.597 & & 12.494 & \\
\hline
\end{tabular}

To test hypothesis 2, we split the sample into two groups based on the CEO tenure. The first group consists of observations whose CEO tenure is shorter than five years $(\mathrm{N}=348)$, while the second group consists of those with five years or longer $(\mathrm{N}=284)$. The result suggests that insider CEOs are associated with higher earnings quality relative to outsider CEOs only in the early years of their tenure. Table 2 shows that for CEOs whose tenure is less than five year, insider CEOs generate higher earnings quality. However, for CEOs whose tenure is five years or longer, we do not find any association between CEO origin and earnings quallity. This could be interpreted as that earnings quality gap between insider and outsider CEOs are more prevalent in the first years. As outsider CEOs have more experience after holding their position for five years or longer, the earnings quality gap between insider CEOs and outsider CEOs become less significant. The result supports H2.

We also conduct additional analysis using accrual quality measure from the model developed by Dechow et al [20]. Generally, the results of the additional analysis (not tabulated) are consistent with the results reported in this study. 


\section{Conclusion}

This study investigates the effect of CEO origin and CEO tenure on earnings quality. We find that compared with outsider CEOs, insider CEOs tend to report earnings with higher quality. However, we find that the effect of CEO origin is prevalent only in the early years of CEO tenure. After five years, we do not find any significant difference in earnings quality between firms with insider CEOs and those with outsider CEOs.

This study contributes to the accounting literature by providing evidence on the effect CEO origin on earnings quality and how CEO tenure moderates the association between the two variables. This study provides insight to investors that hiring CEOs from within provides an advantage in the form of higher earnings quality, at least in the early years, relative to hiring outsiders.

Further studies could investigate more deeply on the relationship of the origin of the CEO and the company's financial reporting behavior in the context of horizon problems. Researcher might also consider factors such as CEO educational background in accounting, accounting certification, whether CEO turnover was routine or nonroutine, and their impacts on earnings quality.

\section{References}

1. Q. Cheng and K. Lo. Journal of Accounting Research. 44, 5, 815-848. (2006)

2. D. Hambrick, and P. Mason. Academy of Management Review. 9: 193 - 206. (1984)

3. W. Shen and A. A. Cannella. The Academy of Management Journal. 45, 4, 717 - 733. (2002)

4. M. F. Wieserman. Human Resource Management. 34, 1, 185 - 202. (1995)

5. Y. F. Kuang, B. Qin, dan J.L. Wielhouwer. Accounting Horizons. 28, 3, $605-626$. (2014)

6. P. R. Demerjian, B. Lev, M. F. Lewis, S. E. McVay. The Accounting Review. 88, 2, 463 - 498. (2013)

7. P. Dechow, W. Ge., and C. Schrand. Journal of Accounting and Economics. 50, $344-$ 401. (2010)

8. H. Li. International Journal of Financial Research. 5, 2, 79 - 86. (2014)

9. W. N. III Davidson, C. Nemec, and D. L. Worrell. Journal of Management and Governance. 10, 35 - 57. (2006)

10. D. Setiawan.International Business and Economics Research Journal. 4, 2, 119 - 128. (2008)

11.Isabelle Dherment-Ferere, and Luc Renneboog. Working papers from www.researchgate.net, issue 2000-70. (2000)

12. R. Gibbons and K. J. Murphy. Working papers from www.researchgate.net. (1991)

13. W. Zhang. Working papers from www.psu.edu. (2009)

14. A. Ali, and W. Zhang. Journal of Accounting and Economics. 59,1,1-118. (2015)

15. K. Kim and J. S. Yang. Review of Integrative Business and Economics Research. 3,1, $237-256 .(2014)$

16. R. D. Santoso. Skripsi FEB UGM. (2013)

17. P. M Dechow, and I. Dichev. The Accounting Review. 77, Supplement, 35 - 59. (2002)

18. J. Francis, A. Huang, S. Rajgopal, and A. Zang. Contemporary Accounting Research. 25, $1,109-147$. (2008)

19. D. Wang. Journal of Accounting Research. 44, 3, 619 - 656. (2006)

20. P. M. Dechow, G. Sloan, and A. P. Sweeney. The Accounting Review. 70, 2, 193 225. (1995) 